\title{
Impact of Cyclin-Dependent Kinase CDK4 Inhibition on Eryptosis
}

\author{
Elisabeth Langa,b Christine Zelenak ${ }^{c}$ Matthias Eberhard ${ }^{a}$ Rosi Bissinger ${ }^{a}$ \\ Anand Rotte $^{\mathrm{d}}$ Mehrdad Ghashghaeinia $^{\mathrm{a}}$ Adrian Lupescu ${ }^{\mathrm{a}} \quad$ Florian Lang ${ }^{\mathrm{a}}$ \\ Syed M. Qadrie
}

${ }^{a}$ Department of Physiology, University of Tuebingen, Tuebingen, Germany; ${ }^{b}$ Department of Gastroenterology, Hepatology and Infectious Diseases, University of Duesseldorf, Duesseldorf,

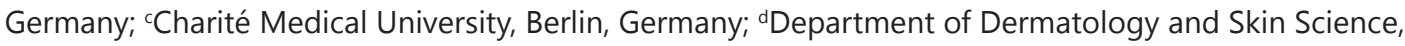
University of British Columbia, Vancouver, Canada; ${ }^{\mathrm{D}}$ Department of Pathology and Molecular Medicine, McMaster University, Hamilton, Canada

\section{Key Words}

CDK4 • Apoptosis $•$ Eryptosis $\bullet$ Cell shrinkage $\bullet$ Calcium

\begin{abstract}
Background/Aims: The cyclin-dependent kinase 4 (CDK4) participates in the regulation of apoptosis of nucleated cells by altering transcriptional regulation of genes governing cell proliferation and cell death. Similar to apoptosis of nucleated cells, erythrocytes may enter eryptosis, which is characterized by cell shrinkage and cell membrane scrambling with phosphatidylserine (PS) exposure at the cell surface. As mature erythrocytes lack nuclei, acute stimulation of eryptosis cannot result from altered gene expression. Eryptosis is triggered by isotonic cell shrinkage following $\mathrm{Cl}^{-}$removal (replacement with the impermeant organic anion gluconate) or by oxidative stress (exposure to $0.3 \mathrm{mM}$ tertbutyl-hydroperoxide [tBOOH]). The present study explored whether CDK4 is expressed in erythrocytes and whether the CDK4 inhibitors II (NSC625987) and III (ryuvidine) influence eryptosis. Methods: Western blotting was utilized for determination of the presence of CDK4 protein in human erythrocytes, and FACS analysis to determine Fluo3 fluorescence (reflecting cytosolic $\mathrm{Ca}^{2+}$ ), annexin-V-binding (reflecting PS-exposure) and forward scatter (reflecting cell volume). Results: CDK4 protein was present in human erythrocytes. $\mathrm{Cl}^{-}$removal was followed by decrease of forward scatter and increase of both annexin-V-binding and Fluo3 fluorescence, an effect significantly curtailed by CDK4 inhibitors II and III. Furthermore, CDK4 inhibition blunted enhanced PS-exposure elicited by $\mathrm{tBOOH}$ treatment. Conclusions: The present observations disclose the presence of CDK4 protein in human erythrocytes and the suppression of suicidal erythrocyte death by pharmacological inhibition of CDK4.
\end{abstract}

Prof. Dr. Florian Lang

KARGER 125
Department of Physiology, University of Tuebingen,

Gmelinstr. 5, 72076 Tuebingen, (Germany)

Tel. +4970712972194, Fax +497071295618, E-Mail florian.lang@uni-tuebingen.de 


\begin{tabular}{|c|c|c|}
\hline Cellular Physiology & Cell Physiol Biochem 2015;37:1178-1186 & \\
\hline and Biochemistry & $\begin{array}{l}\text { DOI: } 10.1159 / 000430241 \\
\text { Published online: September 29, } 2015\end{array}$ & $\begin{array}{l}\text { O } 2015 \text { S. Karger AG, Basel } \\
\text { www.karger.com/cpb }\end{array}$ \\
\hline
\end{tabular}

\section{Introduction}

The cyclin-dependent kinase 4 (CDK4) participates in the regulation of cell cycle progression and transcription [1]. Increased activity of cyclin-dependent kinases including CDK4 is observed in cancer and CDK inhibition has been shown to induce G1 arrest and apoptosis [2-8]. The efficacy of CDK inhibitors is primarily attributed to altered transcription of antiapoptosis family members, cell cycle regulators, as well as p53 and NF- $\mathrm{kB}$-responsive gene targets $[1,9]$. On the other hand, CDK4 has been implicated in the regulation of neuronal cell death [10]. Activation of CDK4 leads to hyper-phosphorylation of the $\mathrm{pRb}$ family member p130 with subsequent p130 dissociation from the transcription factor E2F4 and expression of E2F binding genes including the transcription factors B- and C-Myb, which in turn stimulate the expression of the pro-apoptotic BH3-only protein Bim [10]. Furthermore, CDK4 is a powerful modulator of mitochondrial functions via phosphorylation of mitochondrial targets [11].

Similar to the apoptosis of nucleated cells, erythrocytes are able to undergo suicidal death called eryptosis $[12,13]$. Triggers of eryptosis include activation of $\mathrm{Ca}^{2+}$-permeable cation channels with $\mathrm{Ca}^{2+}$ entry, activation of $\mathrm{Ca}^{2+}$-sensitive $\mathrm{K}^{+}$channels, exit of $\mathrm{KCl}$ with osmotically obliged water and, thus, cell shrinkage. Cytosolic $\mathrm{Ca}^{2+}$ further elicits scrambling of the erythrocyte membrane resulting in phosphatidylserine (PS) externalization [13]. Extracellular $\mathrm{Cl}^{-}$-sensitive osmotic shrinkage opens eryptosis-triggering non-selective cation channels in the erythrocyte cell membrane which are also activated by oxidative stress [12]. As erythrocytes are devoid of nuclei, any stimulators or inhibitors of eryptosis must be effective without influencing gene expression [13].

The present study explored whether CDK4 protein is present in erythrocytes and if so, whether it influences eryptosis.

\section{Materials and Methods}

\section{Erythrocytes, incubations and solutions}

Leukocyte-depleted erythrocytes from concentrates were provided by the blood bank of the University of Tübingen. The volunteers providing erythrocytes gave informed consent. The study has been approved by the Ethical commission of the University of Tübingen. The erythrocytes were incubated at $37^{\circ} \mathrm{C}$ in Ringer solution containing (in mM): $125 \mathrm{NaCl}, 5 \mathrm{KCl}, 1 \mathrm{MgSO}_{4}$, and $32 \mathrm{HEPES} / \mathrm{NaOH}$ (pH 7.4), 5 glucose, and $1 \mathrm{CaCl}_{2}$ at a hematocrit of $0.4 \%$ in a total volume of $1 \mathrm{ml}$. Where indicated, chloride was replaced by gluconate or $0.3 \mathrm{mM}$ tert-butyl hydroperoxide [tBOOH] added to the Ringer solution. The CDK4 inhibitors II (1, 4-Dimethoxyacridine-9(10H)thione, NSC 625987) and III (5-(N-(4-Methylphenyl)amino)-2-methyl-4,7-dioxobenzothiazole, ryuvidine), purchased from Calbiochem (Cat \#: 219477 and 219478, Bad Soden, Germany), were dissolved in DMSO and added to the respective solutions, at concentrations as indicated. Solvent $(0.1 \%)$ did not influence annexin $\mathrm{V}$ binding (data not shown).

\section{Western blotting}

To examine the presence of CDK4 protein in human erythrocytes, $150 \mu$ l erythrocyte pellet was lysed in $50 \mathrm{ml}$ of $20 \mathrm{mM} \mathrm{N}$-2-hydroxyethylpiperazine-N-2-ethanesulfonic acid (HEPES)/NaOH (pH 7.4). Ghost membranes were pelleted $\left(15,000 \mathrm{~g}\right.$ for $20 \mathrm{~min}$ at $\left.4^{\circ} \mathrm{C}\right)$ and lysed in $200 \mu \mathrm{llysis}$ buffer $(50 \mathrm{mM}$ Tris- $\mathrm{HCl}$, pH 7.5, $150 \mathrm{mM} \mathrm{NaCl}, 1 \%$ Triton X-100, 0.5\% SDS, 1mM NaF, $1 \mathrm{mM} \mathrm{Na}_{3} \mathrm{VO}_{4}, 0.4 \%$ ß-mercaptoethanol) containing protease inhibitor cocktail (Sigma, Taufkirchen, Germany). For whole erythrocyte lysates, $4 \mu \mathrm{l}$ of erythrocytes were lysed in $200 \mu$ lysis buffer. In all cases, $80 \mu \mathrm{g}$ of protein were solubilized in Laemmli sample buffer at $95^{\circ} \mathrm{C}$ for $5 \mathrm{~min}$ and resolved by $10 \%$ SDS-PAGE. For immunoblotting, proteins were electrotransferred onto a PVDF membrane and blocked with 5\% nonfat milk in TBS-0.10\% Tween 20 (TBST) at room temperature for $1 \mathrm{~h}$. Then, the membrane was incubated with monoclonal mouse anti-CDK4 antibody (1:2000; $30 \mathrm{kDa}$, Cell Signaling, Freiburg, Germany) at $4^{\circ} \mathrm{C}$ overnight. After washing 3 times with TBST (10 min each), the blots were incubated with horseradish peroxidase conjugated secondary anti-rabbit antibody (1:2000; Cell Signaling) for $1 \mathrm{~h}$ at room temperature. After washing, antibody binding was detected with the 


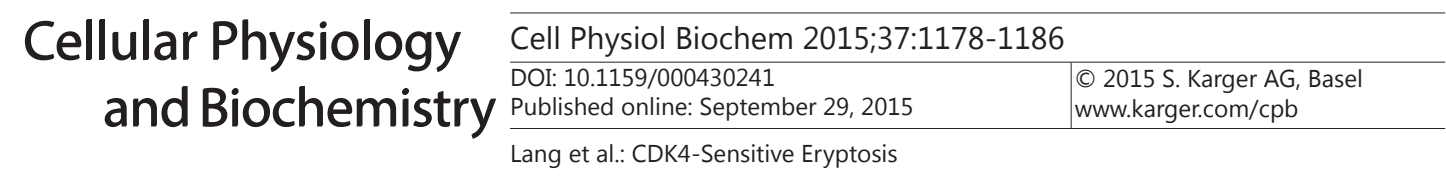

ECL detection reagent (Amersham, Freiburg, Germany). Antibody-binding was detected with Quantity One Software (Biorad, München, Germany).

\section{Determination of phosphatidylserine exposure and forward scatter}

For FACS analysis erythrocytes were washed after incubation once in Ringer solution containing $5 \mathrm{mM}$ $\mathrm{CaCl}_{2}$. The cells were then stained with Annexin V-Fluos (Roche, Mannheim, Germany) at a 1:500 dilution. After $15 \mathrm{~min}$, samples were measured by flow cytometric analysis (FACS-Calibur from Becton Dickinson; Heidelberg, Germany). Cells were analysed by forward scatter, and annexin V-fluorescence intensity was measured in fluorescence channel FL-1 with an excitation wavelength of $488 \mathrm{~nm}$ and an emission wavelength of $530 \mathrm{~nm}$.

\section{Measurement of intracellular $\mathrm{Ca}^{2+}$}

After incubation $50 \mu \mathrm{l}$ suspension erythrocytes were washed in Ringer solution and then loaded with Fluo-3/AM (Calbiochem, Bad Soden, Germany) in Ringer solution containing $5 \mathrm{mM} \mathrm{CaCl}_{2}$ and $2 \mu \mathrm{M}$ Fluo-3/ AM. The cells were incubated at $37^{\circ} \mathrm{C}$ for 20 min and washed twice in Ringer solution containing $5 \mathrm{mM} \mathrm{CaCl}_{2}$. The Fluo-3/AM-loaded erythrocytes were resuspended in $200 \mu$ l Ringer. Then, $\mathrm{Ca}^{2+}$-dependent fluorescence intensity was measured in fluorescence channel FL-1 in FACS analysis.

\section{Statistics}

Data are expressed as arithmetic mean \pm SEM, and statistical analysis was made by paired ANOVA with Tukey's test as post-test. Values of $p<0.05$ were considered statistically significant. $n$ denotes the number of different erythrocyte specimens studied.

\section{Results}

According to Western blotting, human erythrocytes express the protein kinase CDK4. As shown in Fig. 1, the respective bands show the presence of CDK4 protein in membrane lysates from isolated human erythrocytes as well as from whole blood. Bands in K562 cell lysates were slightly higher presumably due to differential posttranslational modification of CDK4 in K562 cells as compared to erythrocytes. Whole cell lysates from isolated human erythrocytes further showed CDK4 expression. Further experiments were performed to elucidate, whether CDK4 is involved in the regulation of suicidal erythrocyte death or eryptosis.

In a first series of experiments, eryptosis was stimulated by replacement of $\mathrm{Cl}^{-}$with gluconate, which leads to profound isosmotic cell shrinkage due to exit of $\mathrm{Cl}^{-}$paralleled by $\mathrm{K}^{+}$exit. According to forward scatter, which reflects alterations of cell volume, $\mathrm{Cl}^{-}$removal was followed by a sharp, significant decrease of cell volume (Fig. 2A and 2B). As shown in Fig. 2A and 2B, addition of CDK4 inhibitor II and III did not significantly modify erythrocyte forward scatter in the presence of $\mathrm{Cl}^{-}$ions. However, cell shrinkage following $\mathrm{Cl}^{-}$removal was significantly abated by treatment with CDK4 inhibitor III but not by CDK4 inhibitor II (Fig. 2A and 2B). $\mathrm{Cl}^{-}$removal is a powerful inducer of PS-externalization on the erythrocyte membrane. PS-exposing erythrocytes were identified in FACS analysis utilizing annexinV-binding. To this end, $\mathrm{Cl}$ removal was followed by the expected significant increase in annexin-V-binding (Fig. 2C and 2D). Addition of CDK4 inhibitor II did not significantly alter PS-exposure in the presence of extracellular $\mathrm{Cl}^{-}$ions but significantly blunted PS-exposure

Fig. 1. Presence of CDK4 in human erythrocytes. Original Western blots demonstrating the presence of CDK4 (30 kDa) protein in membranes from isolated human erythrocytes and from whole blood as well as lysates from K562 cells and whole erythrocytes.

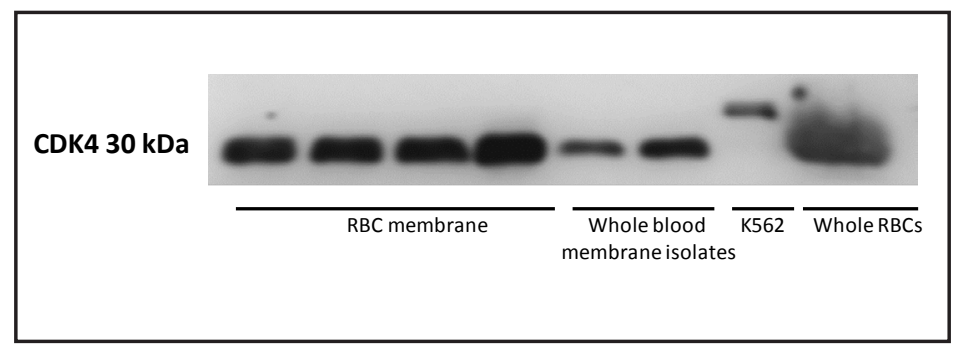




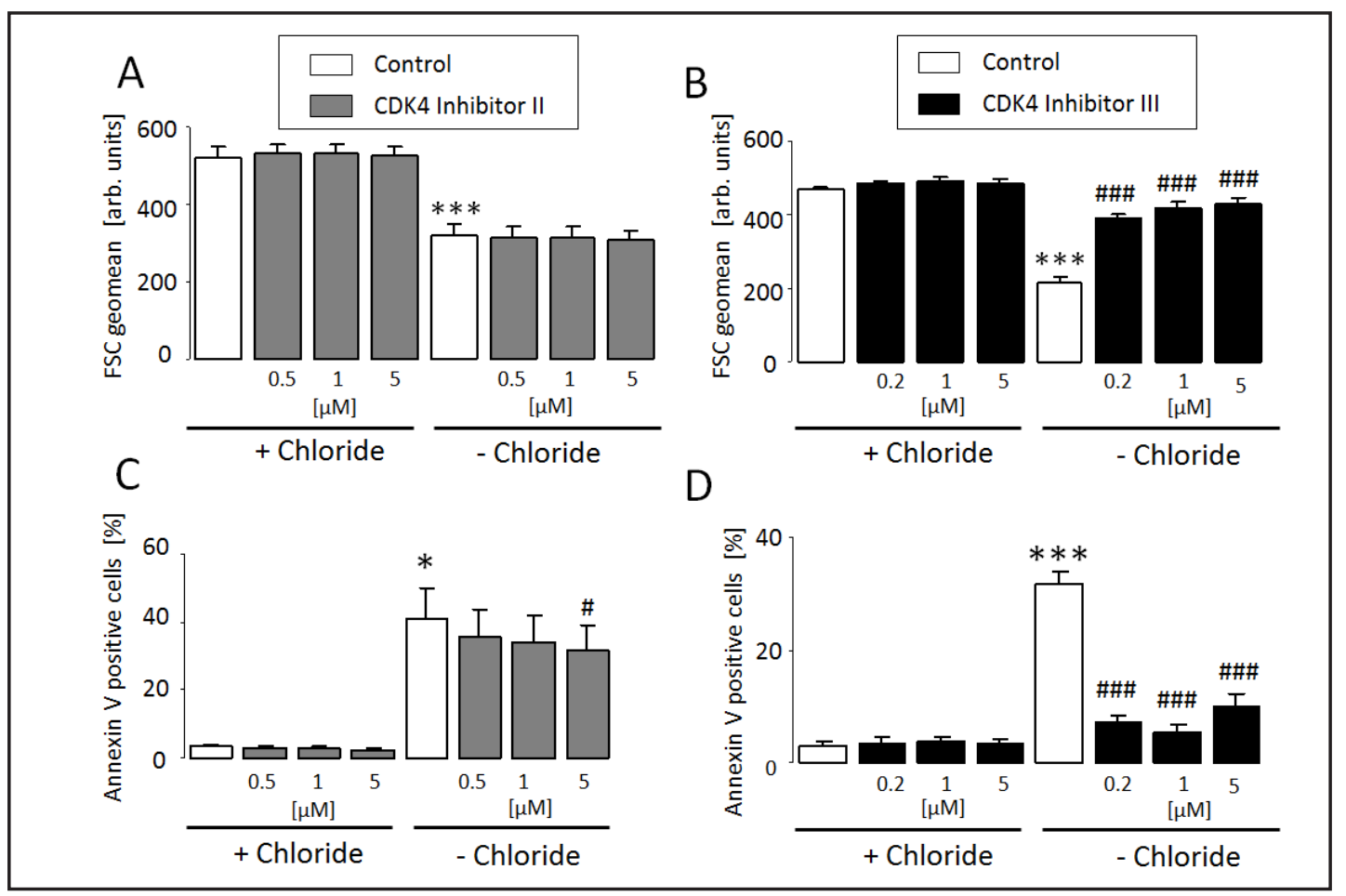

Fig. 2. Effect of CDK4 inhibitors on erythrocyte cell shrinkage and phosphatidylserine externalization following extracellular $\mathrm{Cl}^{-}$removal. (A, B) Means \pm SEM of forward scatter geomean determined in erythrocytes incubated for $48 \mathrm{~h}$ in Ringer solution (left bars) or chloride-free Ringer solution (right bars) in the absence (Control) or in the presence of $0.5-5 \mu \mathrm{M}$ CDK4 inhibitor II (A, gray bars, $\mathrm{n}=13$ ) or $0.2-5 \mu \mathrm{M}$ CDK4 inhibitor III (B, black bars, $\mathrm{n}=16)$. ${ }^{* * *}$ significant $(\mathrm{p}<0.001)$ from the presence of $\mathrm{Cl}^{-}$ions. \#\#\# significant $(\mathrm{p}<0.001)$ from the absence of inhibitor. (C, D) Means \pm SEM of PS-exposure determined in erythrocytes incubated for $48 \mathrm{~h}$ in Ringer solution (left bars) or chloride-free Ringer solution (right bars) in the absence (Control) or in the presence of $0.5-5 \mu \mathrm{M}$ CDK4 inhibitor II (C, gray bars, $\mathrm{n}=13$ ) or $0.2-5 \mu \mathrm{M}$ CDK4 inhibitor III (D, black bars, $\mathrm{n}=16)$. *, *** significant $(\mathrm{p}<0.05, \mathrm{p}<0.001)$ from the presence of $\mathrm{Cl}^{-}$ions. \#, \#\#\# significant $(\mathrm{p}<0.05, \mathrm{p}<0.001)$ from the absence of inhibitor.

in the absence of $\mathrm{Cl}^{-}$ions, an effect reaching statistical significance at a concentration of 5 $\mu \mathrm{M}$ (Fig. 2C). Similarly, the CDK4 inhibitor III did not significantly modify PS-exposure in the presence of extracellular $\mathrm{Cl}^{-}$ions but significantly attenuated PS-exposure in the absence of $\mathrm{Cl}^{-}$ions, an effect reaching statistical significance at a concentration of $0.2 \mu \mathrm{M}$ (Fig. 2C).

Enhanced PS-exposure following $\mathrm{Cl}^{-}$removal is known to be stimulated by nonselective cation channels which elicit increased cytosolic $\mathrm{Ca}^{2+}$ activity in erythrocytes. Thus, Fluo3 fluorescence was employed to determine erythrocyte $\mathrm{Ca}^{2+}$. As shown in Fig. $3 \mathrm{~A}$ and $3 \mathrm{~B}, \mathrm{Cl}^{-}$ removal significantly increased Fluo3 fluorescence. Treatment with CDK4 inhibitors II and III did not significantly modify Fluo 3 fluorescence in the presence of extracellular $\mathrm{Cl}^{-}$ions but markedly blunted the increase of Fluo3 fluorescence following $\mathrm{Cl}^{-}$removal, an effect reaching statistical significance at $5 \mu \mathrm{M}$ and $0.2 \mu \mathrm{M}$ concentration respectively for inhibitors II and III (Fig. 3A and 3B).

Additional series of experiments explored the effect of pharmacological inhibition of CDK4 on eryptosis triggered by oxidative stress, which was accomplished by exposure of erythrocytes for 30 minutes to $0.3 \mathrm{mM}$ of the oxidant tert-butyl-hydroperoxide (tBOOH). As illustrated in Fig. 4, exposure to $\mathrm{tBOOH}(0.3 \mathrm{mM})$ was followed by a sharp, significant increase in erythrocyte PS-exposure. The addition of CDK4 inhibitors II and III again did not significantly modify PS-exposure in the absence of tBOOH, but significantly curtailed PS-exposure in the presence of $\mathrm{tBOOH}$ indicating the efficacy of CDK4 inhibitors II and III in curtailing eryptosis triggered by oxidative stress (Fig. 4). 


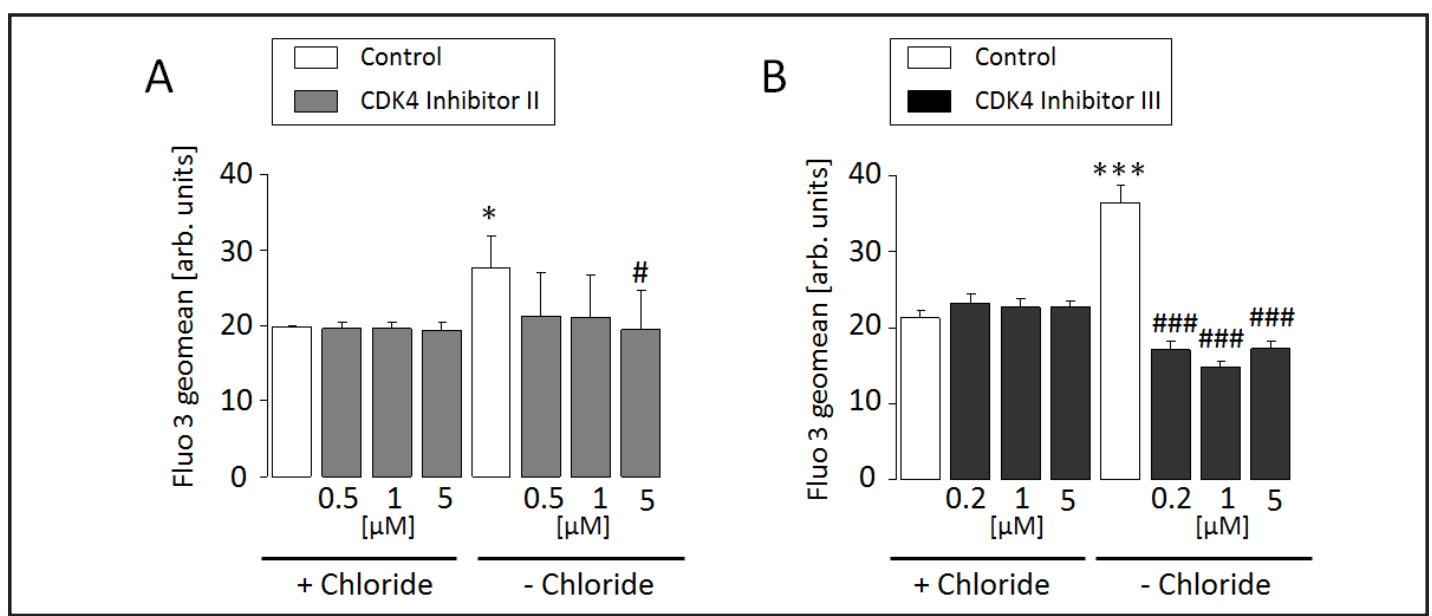

Fig. 3. Effect of CDK4 inhibitors on erythrocyte cytosolic $\mathrm{Ca}^{2+}$ activity following extracellular $\mathrm{Cl}^{-}$removal. (A, B) Means \pm SEM of Fluo3 geomean determined in erythrocytes incubated for $48 \mathrm{~h}$ in Ringer solution (left bars) or chloride-free Ringer solution (right bars) in the absence (Control) or in the presence of $0.5-5 \mu \mathrm{M}$ CDK4 inhibitor II (A, gray bars, $\mathrm{n}=4$ ) or $0.2-5 \mu \mathrm{M}$ CDK4 inhibitor III (B, black bars, $\mathrm{n}=13$ ). *, *** significant $(p<0.05, p<0.001)$ from the presence of $\mathrm{Cl}^{-}$ions. \#, \#\#\# significant $(\mathrm{p}<0.05, \mathrm{p}<0.001)$ from the absence of inhibitor.

Fig. 4. Effect of CDK4 inhibitors on erythrocyte phosphatidylserine externalization following oxidant treatment. Means \pm SEM ( $n=3-7)$ of PS-exposure determined in erythrocytes incubated for 30 min in Ringer solution (left bars) or in Ringer solution containing $0.3 \mathrm{mM}$ tBOOH (right bars) in the absence (Control) or in the presence of $5 \mu \mathrm{M}$ CDK4 inhibitor II (gray bars) or $5 \mu \mathrm{M}$ CDK4 inhibitor III (black bar). ${ }^{* * *}$ significant $(\mathrm{p}<0.001)$ from the $\mathrm{ab}$ sence of $\mathrm{tBOOH}$. \# significant $(\mathrm{p}<0.05)$ from the $a b-$ sence of inhibitor.

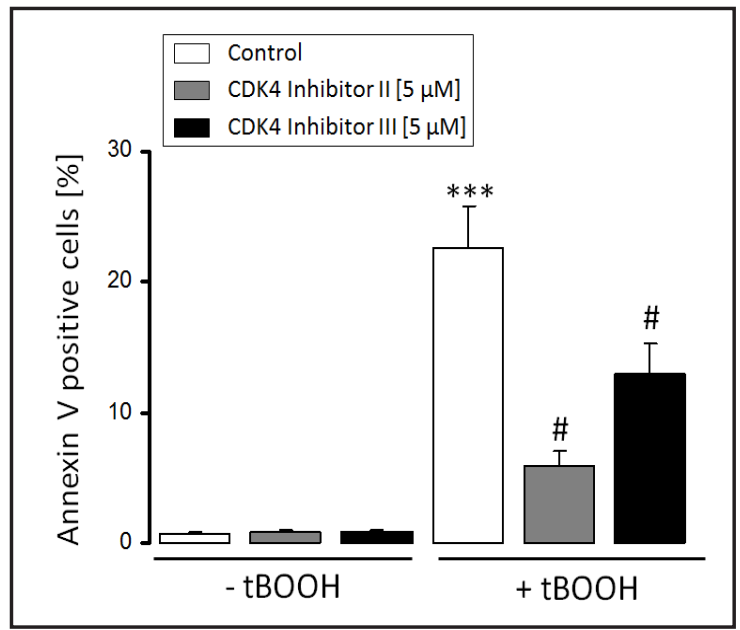

\section{Discussion}

The present observations reveal that the protein kinase CDK4 protein is present in human erythrocytes and that the CDK4 inhibitors II and III significantly interfere with the stimulation of eryptosis following $\mathrm{Cl}$ - depletion and oxidative stress.

Both oxidative stress and removal of extracellular $\mathrm{Cl}^{-}$ions are known to foster increase in cytosolic $\mathrm{Ca}^{2+}$ activity $[12,13]$. Herein, we observed that both CDK4 inhibitors II and III thwart eryptosis by mitigating the increase of cytosolic $\mathrm{Ca}^{2+}$ activity following removal of extracellular $\mathrm{Cl}^{-}$ions. Beyond the activation of scramblase and $\mathrm{Ca}^{2+}$-sensitive $\mathrm{K}^{+}$channels [12], enhanced cytosolic $\mathrm{Ca}^{2+}$ activity participates in the modification of the cytoskeleton and in the activation of a wide variety of $\mathrm{Ca}^{2+}$-sensitive enzymes such as transglutaminase [14], phospholipases [15], calpain [14], protein kinases and phosphatases [16, 17]. Calpain activation is responsible for the membrane blebbing during suicidal erythrocyte death [12].

Recently, hematopoiesis was shown to be affected in mice with a combined deficiency of CDK2 and CDK4 [18]. Interestingly, the combined deficiency of these cyclin-dependent kinases resulted in increased erythrocyte cell volume [18]. The CDK4 inhibitors used in this study are chemically unrelated compounds which have previously been shown to 
potently inhibit CDK4 kinase activity. CDK4 inhibitor II (NSC 625987) is an ATP-competitive thioacridone compound and has been shown to possess a greater selectivity for CDK4 over other cyclin-dependent kinases including CDK1 and CDK2 [19]. On the other hand, the dioxobenzothiazole compound CDK4 inhibitor III (ryuvidine) was reported to suppress CDK4 activity by a higher magnitude as compared to CDK2 kinase [20]. In the present study, we have shown that CDK4 protein is present in human erythrocytes and pharmacological inhibition of CDK4 modulates eryptosis. The broad spectrum of kinase inhibition elicited by these inhibitors and off-target effects, nevertheless, warrants further investigation to clarify the putative role of CDK4 kinase in erythrocyte survival. A wide variety of erythrocyteexpressed kinases further participate in the eryptosis machinery such as AMPK [21], CK1 $\alpha$ [22], Janus kinase 3 [23], p38 MAPK [24] and PAK2 [25]. Whether these kinases influence CDK4 activity during eryptosis remains to be shown.

Oxidative stress is a pathophysiologically relevant trigger of suicidal erythrocyte death in vivo as many clinical conditions with enhanced eryptosis are also associated with redox imbalance [26, 27]. Animal experiments have confirmed that erythrocytes subjected to oxidative stress have reduced lifespan in vivo and are rapidly cleared from the circulation [28]. Interestingly, cellular redox balance is decisive in the regulation of cyclin-dependent kinase-sensitive cell cycle [29] which fosters the convergence of different cell cycle signaling pathways on regulators of cyclin-dependent kinase activity such as p16, p27, and cyclin D1 $[30,31]$. Due to the absence of key organelles, nucleus and mitochondria, it is not known whether these mechanisms could similarly be operative in erythrocytes.

Noticeably, we observed that the CDK4 inhibitors attenuated oxidant-induced eryptosis with different efficacies in contrast to the inhibition of eryptosis following removal of extracellular $\mathrm{Cl}^{-}$ions. According to our data, CDK4 inhibitor III showed a more robust amelioration of cytosolic $\mathrm{Ca}^{2+}$ activity as compared to inhibitor II following removal of extracellular $\mathrm{Cl}^{-}$ions. Removal of $\mathrm{Cl}^{-}$ions triggers $\mathrm{PGE}_{2}$ release which, in turn is associated with activation of non-selective cation channels and subsequent upregulation of cytosolic $\mathrm{Ca}^{2+}$ activity [32]. On the other hand, oxidative stress, in addition to enhanced cytosolic $\mathrm{Ca}^{2+}$ activity, is also associated with activation of caspases [27] and [33]. It is, therefore, possible that the CDK4 inhibitors II and III differentially target these mechanisms, independently of CDK4 kinase inhibition, in mitigating eryptosis due to oxidative stress or removal of extracellular $\mathrm{Cl}^{-}$ions.

Eryptosis is enhanced by erythrocyte age [34], and is triggered by a wide variety of anemia-causing xenobiotics and endogeneous substances [35-48]. Furthermore, eryptosis participates in the pathophysiology of several clinical disorders such as iron deficiency, hepatic failure, chronic kidney disease, sepsis, malignancy, Wilson's disease and presumably metabolic syndrome [12, 13, 49-51]. Eryptosis may further influence erythrocytes stored for transfusion [52]. Eryptotic erythrocytes are rapidly phagocytosed and cleared from circulating blood, thus enhancing the risk of anemia [12]. Eryptosis further stimulates blood clotting [53] and may compromise microcirculation by increased adhesion of eryptotic erythrocytes to the vascular wall [54].

In conclusion, the present observations demonstrate that erythrocytes express CDK4 and provide evidence that pharmacological CDK4 inhibition interferes with suicidal erythrocyte death.

\section{Acknowledgments}

The authors acknowledge meticulous preparation of the manuscript by Tanja Loch. This study was supported by the Deutsche Forschungsgemeinschaft (GRK 1302, SFB 773, La 315/13-3) and Open Access Publishing Fund of Tübingen University. 


\begin{tabular}{|c|c|c|}
\hline Cellular Physiology & Cell Physiol Biochem 2015;37:1178-1186 & \\
\hline and Biochemistry & $\begin{array}{l}\text { Dol: 10.1159/000430241 } \\
\text { Published online: September 29, } 2015\end{array}$ & $\begin{array}{l}\text { O } 2015 \text { S. Karger AG, Basel } \\
\text { www.karger.com/cpb }\end{array}$ \\
\hline
\end{tabular}

\section{Disclosure Statement}

The authors of this manuscript state that they do not have any conflict of interests and nothing to disclose.

\section{References}

1 Shapiro GI: Cyclin-dependent kinase pathways as targets for cancer treatment. J Clin Oncol 2006;24:17701783.

2 Aggarwal BB, Ichikawa H: Molecular targets and anticancer potential of indole-3-carbinol and its derivatives. Cell Cycle 2005;4:1201-1215.

3 Ibrahim N, Haluska FG: Molecular pathogenesis of cutaneous melanocytic neoplasms. Annu Rev Pathol 2009;4:551-579.

4 Nelson AA, Tsao H: Melanoma and genetics. Clin Dermatol 2009;27:46-52.

5 Choi YJ, Anders L: Signaling through cyclin D-dependent kinases. Oncogene 2014;33:1890-1903.

6 Han YK, Lee JH, Park GY, Chun SH, Han JY, Kim SD, Lee J, Lee CW, Yang K, Lee CG: A possible usage of a CDK4 inhibitor for breast cancer stem cell-targeted therapy. Biochem Biophys Res Commun 2013;430:13291333.

7 Lee W, Kim KY, Yu SN, Kim SH, Chun SS, Ji JH, Yu HS, Ahn SC: Pipernonaline from Piper longum Linn. induces ROS-mediated apoptosis in human prostate cancer PC-3 cells. Biochem Biophys Res Commun 2013;430:406-412.

8 Wu Q, Kang Y, Zhang H, Wang H, Liu Y, Wang J: The anticancer effects of hispolon on lung cancer cells. Biochem Biophys Res Commun 2014;453:385-391.

9 Sheppard KE, McArthur GA: The cell-cycle regulator CDK4: an emerging therapeutic target in melanoma. Clin Cancer Res 2013;19:5320-5328.

10 Greene LA, Liu DX, Troy CM, Biswas SC: Cell cycle molecules define a pathway required for neuron death in development and disease. Biochim Biophys Acta 2007;1772:392-401.

11 Alexandrou AT, Li JJ: Cell cycle regulators guide mitochondrial activity in radiation-induced adaptive response. Antioxid Redox Signal 2014;20:1463-1480.

12 Lang E, Qadri SM, Lang F: Killing me softly - suicidal erythrocyte death. Int J Biochem Cell Biol 2012;44:1236-1243.

13 Lang F, Qadri SM: Mechanisms and significance of eryptosis, the suicidal death of erythrocytes. Blood Purif 2012;33:125-130.

14 Anderson DR, Davis JL, Carraway KL: Calcium-promoted changes of the human erythrocyte membrane. Involvement of spectrin, transglutaminase, and a membrane-bound protease. J Biol Chem 1977;252:66176623.

15 Allan D, Billah MM, Finean JB, Michell RH: Release of diacylglycerol-enriched vesicles from erythrocytes with increased intracellular (Ca2+). Nature 1976;261:58-60.

16 Cohen CM, Gascard P: Regulation and post-translational modification of erythrocyte membrane and membrane-skeletal proteins. Semin Hematol 1992;29:244-292.

17 Minetti G, Piccinini G, Balduini C, Seppi C, Brovelli A: Tyrosine phosphorylation of band 3 protein in $\mathrm{Ca} 2+$ / A23187-treated human erythrocytes. Biochem J 1996;320:445-450.

18 Jayapal SR, Wang CQ Bisteau X, Caldez MJ, Lim S, Tergaonkar V, Osato M, Kaldis P: Hematopoiesis specific loss of Cdk2 and Cdk4 results in increased erythrocyte size and delayed platelet recovery following stress. Haematologica 2015;100:431-438.

19 Kubo A, Nakagawa K, Varma RK, Conrad NK, Cheng JQ Lee WC, Testa JR, Johnson BE, Kaye FJ, Kelley MJ: The p16 status of tumor cell lines identifies small molecule inhibitors specific for cyclin-dependent kinase 4. Clin Cancer Res 1999;5:4279-4286.

20 Ryu CK, Kang HY, Lee SK, Nam KA, Hong CY, Ko WG, Lee BH: 5-Arylamino-2-methyl-4,7dioxobenzothiazoles as inhibitors of cyclin-dependent kinase 4 and cytotoxic agents. Bioorg Med Chem Lett 2000;10:461-464.

21 Foller M, Sopjani M, Koka S, Gu S, Mahmud H, Wang K, Floride E, Schleicher E, Schulz E, Munzel T, Lang F: Regulation of erythrocyte survival by AMP-activated protein kinase. FASEB J 2009;23:1072-1080. 


\section{Cellular Physiology Cell Physiol Biochem 2015;37:1178-1186 \begin{tabular}{l|l|l}
\hline DOI: 10.1159/000430241 & (C) 2015 S. Karger AG, Basel
\end{tabular} and Biochemistry Published online: September 29, 2015 \\ Lang et al.: CDK4-Sensitive Eryptosis}

22 Zelenak C, Eberhard M, Jilani K, Qadri SM, Macek B, Lang F: Protein kinase CK1alpha regulates erythrocyte survival. Cell Physiol Biochem 2012;29:171-180.

23 Bhavsar SK, Gu S, Bobbala D, Lang F: Janus kinase 3 is expressed in erythrocytes, phosphorylated upon energy depletion and involved in the regulation of suicidal erythrocyte death. Cell Physiol Biochem 2011;27:547-556.

24 Gatidis S, Zelenak C, Fajol A, Lang E, Jilani K, Michael D, Qadri SM, Lang F: p38 MAPK activation and function following osmotic shock of erythrocytes. Cell Physiol Biochem 2011;28:1279-1286.

25 Zelenak C, Foller M, Velic A, Krug K, Qadri SM, Viollet B, Lang F, Macek B: Proteome analysis of erythrocytes lacking AMP-activated protein kinase reveals a role of PAK2 kinase in eryptosis. J Proteome Res 2011;10:1690-1697.

26 Lang E, Lang F: Triggers, inhibitors, mechanisms, and significance of eryptosis: the suicidal erythrocyte death. Biomed Res Int 2015;2015:513518.

27 Lang F, Abed M, Lang E, Foller M: Oxidative stress and suicidal erythrocyte death. Antioxid Redox Signal 2014;21:138-153.

28 Zidova Z, Kapralova K, Koralkova P, Mojzikova R, Dolezal D, Divoky V, Horvathova M: DMT1-mutant erythrocytes have shortened life span, accelerated glycolysis and increased oxidative stress. Cell Physiol Biochem 2014;34:2221-2231.

29 Burhans WC, Heintz NH: The cell cycle is a redox cycle: linking phase-specific targets to cell fate. Free Radic Biol Med 2009;47:1282-1293.

30 Menon SG, Goswami PC: A redox cycle within the cell cycle: ring in the old with the new. Oncogene 2007;26:1101-1109.

31 Martin EA, Robinson PJ, Franklin RA: Oxidative stress regulates the interaction of p16 with Cdk4. Biochem Biophys Res Commun 2000;275:764-767.

32 Lang PA, Kempe DS, Myssina S, Tanneur V, Birka C, Laufer S, Lang F, Wieder T, Huber SM: PGE(2) in the regulation of programmed erythrocyte death. Cell Death Differ 2005;12:415-428.

33 Matarrese P, Straface E, Pietraforte D, Gambardella L, Vona R, Maccaglia A, Minetti M, Malorni W: Peroxynitrite induces senescence and apoptosis of red blood cells through the activation of aspartyl and cysteinyl proteases. FASEB J 2005;19:416-418.

34 Ghashghaeinia M, Cluitmans JC, Akel A, Dreischer P, Toulany M, Koberle M, Skabytska Y, Saki M, Biedermann T, Duszenko M, Lang F, Wieder T, Bosman GJ: The impact of erythrocyte age on eryptosis. Br J Haematol 2012;157:606-614.

35 Ahmed MS, Langer H, Abed M, Voelkl J, Lang F: The uremic toxin acrolein promotes suicidal erythrocyte death. Kidney Blood Press Res 2013;37:158-167.

36 Alzoubi K, Calabro S, Bissinger R, Abed M, Faggio C, Lang F: Stimulation of suicidal erythrocyte death by artesunate. Cell Physiol Biochem 2014;34:2232-2244.

37 Voelkl J, Alzoubi K, Mamar AK, Ahmed MS, Abed M, Lang F: Stimulation of suicidal erythrocyte death by increased extracellular phosphate concentrations. Kidney Blood Press Res 2013;38:42-51.

38 Bissinger R, Lupescu A, Zelenak C, Jilani K, Lang F: Stimulation of eryptosis by cryptotanshinone. Cell Physiol Biochem 2014;34:432-442.

39 Lupescu A, Shaik N, Jilani K, Zelenak C, Lang E, Pasham V, Zbidah M, Plate A, Bitzer M, Foller M, Qadri SM, Lang F: Enhanced erythrocyte membrane exposure of phosphatidylserine following sorafenib treatment: an in vivo and in vitro study. Cell Physiol Biochem 2012;30:876-888.

40 Lupescu A, Bissinger R, Herrmann T, Oswald G, Jilani K, Lang F: Induction of suicidal erythrocyte death by novobiocin. Cell Physiol Biochem 2014;33:670-680.

41 Lupescu A, Jilani K, Zbidah M, Lang F: Patulin-induced suicidal erythrocyte death. Cell Physiol Biochem 2013;32:291-299.

42 Bissinger R, Fischer S, Jilani K, Lang F: Stimulation of erythrocyte death by phloretin. Cell Physiol Biochem 2014;34:2256-2265.

43 Malik A, Bissinger R, Calabro S, Faggio C, Jilani K, Lang F: Aristolochic acid induced suicidal erythrocyte death. Kidney Blood Press Res 2014;39:408-419.

44 Jilani K, Qadri SM, Lang F: Geldanamycin-induced phosphatidylserine translocation in the erythrocyte membrane. Cell Physiol Biochem 2013;32:1600-1609.

45 Bissinger R, Modicano P, Frauenfeld L, Lang E, Jacobi J, Faggio C, Lang F: Estramustine-induced suicidal erythrocyte death. Cell Physiol Biochem 2013;32:1426-1436. 


\section{Cellular Physiology Cell Physiol Biochem 2015;37:1178-1186 \begin{tabular}{ll|l} 
and Biochemistry 10.1159/000430241 & $\begin{array}{l}\text { O 2015 S. Karger AG, Basel } \\
\text { www.karger.com/cpb }\end{array}$ \\
\hline Published online: September 29, 2015 &
\end{tabular} \\ Lang et al.: CDK4-Sensitive Eryptosis}

46 Ghashghaeinia M, Cluitmans JC, Toulany M, Saki M, Koberle M, Lang E, Dreischer P, Biedermann T, Duszenko M, Lang F, Bosman GJ, Wieder T: Age sensitivity of NFkappaB abundance and programmed cell death in erythrocytes induced by NFkappaB inhibitors. Cell Physiol Biochem 2013;32:801-813.

47 Jacobi J, Lang E, Bissinger R, Frauenfeld L, Modicano P, Faggio C, Abed M, Lang F: Stimulation of erythrocyte cell membrane scrambling by mitotane. Cell Physiol Biochem 2014;33:1516-1526.

48 Lupescu A, Bissinger R, Warsi J, Jilani K, Lang F: Stimulation of erythrocyte cell membrane scrambling by gedunin. Cell Physiol Biochem 2014;33:1838-1848.

49 Qadri SM, Mahmud H, Lang E, Gu S, Bobbala D, Zelenak C, Jilani K, Siegfried A, Foller M, Lang F: Enhanced suicidal erythrocyte death in mice carrying a loss-of-function mutation of the adenomatous polyposis coli gene. J Cell Mol Med 2012;16:1085-1093.

50 Lang E, Gatidis S, Freise NF, Bock H, Kubitz R, Lauermann C, Orth HM, Klindt C, Schuier M, Keitel V, Reich M, Liu G, Schmidt S, Xu HC, Qadri SM, Herebian D, Pandyra AA, Mayatepek E, Gulbins E, Lang F, Haussinger D, Lang KS, Foller M, Lang PA: Conjugated bilirubin triggers anemia by inducing erythrocyte death. Hepatology 2015;61:275-284.

51 Zappulla D: Environmental stress, erythrocyte dysfunctions, inflammation, and the metabolic syndrome: adaptations to CO2 increases? J Cardiometab Syndr 2008;3:30-34.

52 Kriebardis AG, Antonelou MH, Stamoulis KE, Economou-Petersen E, Margaritis LH, Papassideri IS: Progressive oxidation of cytoskeletal proteins and accumulation of denatured hemoglobin in stored red cells. J Cell Mol Med 2007;11:148-155.

53 Chung SM, Bae ON, Lim KM, Noh JY, Lee MY, Jung YS, Chung JH: Lysophosphatidic acid induces thrombogenic activity through phosphatidylserine exposure and procoagulant microvesicle generation in human erythrocytes. Arterioscler Thromb Vasc Biol 2007;27:414-421.

54 Borst O, Abed M, Alesutan I, Towhid ST, Qadri SM, Foller M, Gawaz M, Lang F: Dynamic adhesion of eryptotic erythrocytes to endothelial cells via CXCL16/SR-PSOX. Am J Physiol Cell Physiol 2012;302:C644-C651. 